\title{
STRATEGI PENYELENGGARAAN SISTEM PENGAJARAN NASIONAL (Analisis Teoretik terhadap Kurikulum, Pembelajaran, Evaluasi, dan Guru)
}

\author{
Slamet Hamid \\ Program Studi Bimbingan dan Konseling, \\ Fakultas Ilmu Pendidikan dan Pengetahuan Sosial, Universitas Indraprasta PGRI \\ Email: hamid_slamet1960@gmail.com
}

Diterima: Februari; Disetujui: Maret; dipublikasikan: 28 April 2019

\begin{abstract}
There have been several changes in the primary and secondary school curriculum system ever since Indonesia gained its independence. The changes could raise several questions due to the important and strategic role of the curriculum in achieving the objective of national education system. This article discusses several issues related of the national instructional system, particularly about (1) the role of curriculum as a strategic means in school education, (2) the relevant objectives and contents of the curriculum, (3) the approaches in learning process and their implication to evaluation system, (4) evaluation as an educational medium as well as a feedback instrument, and (5) teachers.
\end{abstract}

Keywords: Curriculum, to Learn, Evaluation System

\begin{abstract}
ABSTRAK
Sejak Indonesia merdeka, telah beberapa kali terjadi perubahan kurikulum sekolah dasar dan menengah. Perubahan itu menimbulkan berbagai persoalan baru pada setiap satuan-satuan pendidikan ketika mengimplementasikannya, mengingat peran kurikulum sangat strategis dalam pencapaian tujuan pendidikan nasional.Dalam kaitannya dengan penyelenggaran sistem pengajaran nasional, tulisan ini membahas (1) kurikulum sebagai unsur strategis dalam pendidikan; (2) tujuan dan materi kurikulum yang relevan; (3) pendekatan proses belajar; (4) evaluasi proses pembelajaran; dan (5) peranan guru dan implikasinya terhadap profesionalisasi jabatan guru. Apabila sebuah kurikulum didesain secara sistematis dan dilaksanakan efektif dan efisien, maka kurikulum tersebut mampu mendukung terlaksananya fungsi pendidikan nasional dalam mencerdaskan kehidupan bangsa.
\end{abstract}

Kata kunci: Kurikulum, pilar belajar, dan sistem evaluasi 


\section{PENDAHULUAN}

Perjalanan praktik dan refleksi pendidikan selama Indonesia merdeka belum mengalami kemajuan yang berarti, bahkan boleh dikatakan lemah dalam visi dan misi globalisasi. Namun yang terjadi selama ini hanyalah pergantian kurikulum yang orientasinya bukan pada kepentingan peserta didik secara optimal, tetapi lebih pada kepentingan pemerintah. Padahal kalau kita bijak dalam merencanakan perubahan kurikulum, bukan hanya pada fokus bongkar pasang kurikukulumnya, tetapi adalah bagaimana kurikulum tersebut dapat menunjang sistem pendidikan nasional yang dijadikan sebagai pilar utama pembangunan bangsa di era globalisasi.

Perubahan kurikulum yang terjadi dalam implementasi pendidikan di Indonesia dimulai dari kurikulum tahun1947, tahun 1950, tahun 1964, tahun 1968, tahun 1975, tahun 1984, tahun 1994 dan yang terakhir adalah pemberlakuan kurikulum tahun 2013. Indonesia termasuk Negara yang selalu melakukan evaluasi terhada kurikulum pendidikan. Perubahan kurikulum di Indonesia secara garis besar dapat digolongkan menjadi dua model, yaitu perubahan sebagian dan perubahan total kurikulum. Dikatakan sebagian karena ada perubahan pada saah satu komponen yang berbeda pada kurikulum sebelumnya. Misalnya; (a) perubahan tujuan yang tidak sesuai dengan tuntutan perkembangan iptek dan perkembangan masyarakat, (b) perubahan isi dan termasuk sistem penilaiannya. Hal tersebut bisa kita lihat pada perubahan kurikulum sebelumnya ke kurikulum 2013. Adapun perubahan total terjadi apabila seluruh sistem dan komponen kurikulum berbeda dengan kurikulum sebelumnya. Misalnya, kurikulum 1964 (MANIPOL-USDEK) menjadi kurikulum 1975 (PPSP) atau kurikulum 1984 menjadi kurikulum 1994, dan Kurikulum Berbasis Kompetensi (KBK) 2004 menjadi Kurikulum Tingkat Satuan Pendidikan (KTSP) 2006.

Dari serangkaian perubahan kurikulum yang terjadi, sukar bagi kita untuk menjawab "seberapa besar kurikulum yang telah dan sedang kita implementasikan belum, sudah, atau tidak berhasil mempengaruhi terhadap peningkatan kualitas pendidikan di Indonesia ?". Apalagi dengan kurikulum tahun 2013 yang belum begitu lama diberlakukan, tidak semua satuan-satuan pendidikan, baik pendidikan di tingkat dasar maupun tingkat menengah sanggup mengimplementasikannya hingga saat ini. Dalam konteks terjadinya perubahan kurikulum di Indonesia, analisis dalam tulisan ini tidak berangkat dari hasil evaluasi ilmiah melainkan dari analisis teoretik berdasarkan litelatur.

Atas dasar pertimbangan di atas, lingkup tulisan ini akan mencoba membahas kurikulum sebagi unsur strategis dalam pendidikan, tujuan dan materi yang relevan, solusi terhadap pendekatan proses pembelajaran, evaluasi pembelajaran, dan peran guru sebagai tenaga pendidik yang profesional.

\section{METODE}

Metode dalam kajian yang penulis lakukan adalah studi litelatur (library research), yaitu dengan melakukan pencarian jawaban teoretis dari berbagai referensi berupa buku-buku, jurnal, artikel, atau dokumen yang penulis anggap relevan terhadap permasalahan yang sedang dianalisis. Informasi yang didapat, penulis jadikan rujukan untuk memperkuat dan mengembangkan argumentasi yang ada. Sebelum terjun ke lapangan dalam rangka pengumpulan data dan informasi, penulis terlebih dahulu menentukan topik dan permasalahan. Teknik ini dilakukan untuk mencari dan mengungkap sejumlah teori yang dianggap relevan terhadap topik dan permasalahan yang sedang dihadapi sebagai bahan rujukan dalam pembahasan hasil penelitian. 


\section{HASIL DAN PEMBAHASAN}

\section{Kurikulum sebagai Unsur Strategis dalam Pendidikan}

Sebagai lembaga pendidikan formal, sekolah merupakan lembaga sosial yang sangat strategis dari sistem sosial negara. Di era industrialisasi (abad ke-19), sekolah melahirkan banyak negara menjadi bangsa yang besar, seperti Amerika Serikat, Britania Raya, Jerman, Perancis, Italia, maupun Jepang.

Indonesia terilhami oleh perkembangan negara-negara tersebut sehingga dalam UU diamanatkan tentang pentingnya mencerdaskan kehidupan bangsa, serta memajukan kebudayaan melalui penyelenggaraan sistem pendidikan nasional. Para pendiri Republik sadar akan adanya jurang pemisah antara kondisi yang dicita-citakan, yaitu masyarakat modern dengan kondisi perkembangan masyarakat Indonesia pada saat proklamasi. Karena itu, harapan terbesar dari suatu masyarakat yang melakukan reformasi dan transformasi pendidikan adalah menjadikan lembaga pendidikan sebagai pusat pembudayaan penguasaan ilmu pengetahuan, pembentukan sikap, dan keterampilan bagi masyarakat modern.

Dalam rangka melaksakan reformasi dan trasformasi pendidikan tersebut, pemerintah melalui departemen terkait terus berupaya melakukan perbaikan terhadap unsur-unsur yang terlibat dalam proses pendidikan. Misalnya, dengan meningkatkan kualitas pendidik dan peserta didik, pembelajaran, alat dan media belajar, lingkungan pendidikan, dan termasuk salah satu unsur strategis dalam meningkatkan kualitas pendidikan tersebut adalah kurikulum.

Dalam pelaksanaan kegiatan pendidikan, kurikulum memiliki tiga peran strategis, yaitu peran konservatif, kritis dan evaluatif, serta kreatif dan konstruktif. Dalam peran konservatif, kurikulum ditentukan oleh masyarakat dan kebudayaan tempat sekolah itu berada. Kurikulum merupakan proses transformasi, transmisi, dan penafsiran nilai-nilai budaya yang disampaikan kepada generasi muda melalui proses pendidikan. Oleh karena itu, Tirtaraharja (2000:33), mengatakan bahwa; sebagai proses transformasi budaya, pendidikan diartikan sebagai kegiatan pewaris budaya dari satu generasi ke generasi yang lain. Kebudayaan adalah hasil pengalaman manusia pada masa lampau yang diwariskan kepada anak-anak melalui pendidikan, maka sekolah bertanggung jawab untuk membentuk potensi anak sesuai dengan perkembangan kultur dan kebudayaan melalui transformasi ilmu pengetahuan, sikap, dan keterampilan.

Peran kritis dan evaluatif, dimaksudkan bahwa kurikulum tidak menerima begitu saja budaya yang diwariskan dari generasi yang lama kepada generasi yang baru, kurikulum hendaknya menilai, memilah, dan memilih secara kritis yang berhubungan dengan dinamika perkembangan budaya masyarakat saat ini. Salah satu ciri masyarakat adalah adanya perubahan dan perkembangan budaya. Oleh sebab itu, menurut Tirtarahardja (2000:33), tiga bentuk tranformasi budaya yang dapat dijadikan acuan dalam merencanakan kurikulum, yaitu (a) nilainilai yang masih cocok diteruskan, misalnya, kejujuran, tanggung jawab, dan lain-lain, (b) yang kurang cocok diperbaiki, misalnya;, tata cara perkawinan, (c) yang tidak cocok diganti, misalnya, pendidikan seks yang dulu ditabukan diganti dengan pendidikan seks melalui pendidikan formal. Di sinilah hendaknya kurikulum direncanakan untuk memberikan kesempatan bagi para pendidik agar dapat mengembangkan dan menciptakan sesuatu yang baru (inovatif) untuk kepentingan masyarakat modern seluruhnya.

Selanjutnya, dalam peran kreatif dan konstruktif, kurikulum harus direncanakan dan disusun secara kreatif dan konstruktif berdasarkan kebutuhan dan tingkat perkembangan potensi psikofisik peserta didik. Kurikulum memberikan kesempatan bagi peserta didik dapat untuk menciptakan sesuatu yang baru. Jhon Dewey (Ansyar (1989:4), peran kreatif kurikulum menekankan pada pengembangan semua potensi yang dimiliki individu, meliputi pengembangan kemampuan kreativitas, kebebasan berpikir, serta pengembangan fisik dan mental (hard skill dan soft skill). Bentuk pertanggungjawaban sebuah kurikulum ketika diimplementasikan dalam proses pendidikan adalah terbentuknya semua potensi (pengetahuan, 
sikap, dan keterampilan) peserta didik secara optimal. Sehingga pembentukan tersebut akan memberikan manfaat bagi setiap peserta didik dalam hidup bermasyarakat.

Selain peran di atas, kurikulum juga memiliki fungsi pendidikan dalam pewarisan kebudayaan. (Ansyar, 1989:4), yaitu : (a) Fungsi penyesuaian (the adjustive of adaptive), memfasilitasi peserta didik agar dapat menyesuaikan diri dengan lingkungan. (b) Fungsi integrative (the integrating function), mengintegrasikan potensi peserta didik melalui kegiatan pembelajaran sehingga berguna bagi masyarakat. (c) Fungsi diferensiasi (the differentiating function), memberikan pelayanan terhadap perbedaan kemampuan yang dimiliki dalam pembelajaran. (d) Fungsi persiapan (the propaedeutic function), mempersiapkan peserta didik untuk dapat melajutkan studi demi persiapan dunia kerja. (e) Fungsi pemilihan (the selective function), memberikan kesempatan untuk memilih apa yang diinginkan sesuai dengan bakat dan minat. (f) Fungsi diagnostic (the diagnostic function), memberikan bantuan dan layanan mampu memahami dan menerima dirinya.

Dengan demikian, tujuan pendidikan akan tercapai bila semua unsur yang terkait dalam proses pendidikan termasuk kurikulumnya, saling berhubungan satu sama lain dan dilaksanakan secara terencana, terprogram, efisien, efektif, dan relevan sesuai dengan peran dan fungsinya. Penguasaan ilmu pengetahuan, pembentukan sikap, dan keterampilan pada peserta didik hanya dapat berlangsung dan diperoleh melalui proses pendidikan yang dipedomani oleh unsur-unsur pendidikan yang strategis dan terukur. Mulai dari penentuan tujuan, perencanaan kurikulum, pemilihan bahan yang harus dipelajari, evaluasi yang digunakan, kualitas guru, lingkungan belajar yang kondusif, dan lain-lain.

\section{Tujuan dan Materi yang Relevan bagi Kedudukan Kurikulum yang Strategis}

Tujuan pendidikan nasional (aims) tidak berkaitan langsung dengan hasil pendidikan di sekolah atau hasil proses belajar mengajar di kelas. Tujuan merupakan target yang pencapaiannya jauh dari situasi sekolah dan hasilnya mungkin akan diperoleh setelah proses belajar mengajar di sekolah selesai, seperti rasa tanggung jawab pada negara, menjadi manusia Pancasila, menjadi manusia seutuhnya, dan lain-lain. Oleh karena itu, tujuan pendidikan yang dirumuskan, dalam berbagai UU pendidikan bersifat normatif dan abstrak. Tujuan dikatakan normatif karena mempunyai unsur norma yang bersifat memaksa, tetapi tidak bertentangan dengan hakikat perkembangan peserta didik dan dapat diterima oleh masyarakat sebagai nilai hidup, sedangkan abstrak, karena memuat nilai-nilai yang abstrak (umum, ideal, dan kandungannya luas) sehingga sulit dilaksanakan dalam praktek (Tirtaraharja 2000:38), Tujuan yang tertuang dalam UU No.2 Tahun1989 menginginkan terbentuknya wujud manusia Indonesia terdidik, sebagai manusia yang beriman dan bertaqwa, sehat jasmani dan rohani, memiliki pengetahuan dan keterampilan, berkepribadian yang mantap dan mandiri, serta mempunyai rasa tanggung jawab kemasyarakatan dan kebangsaan. Dalam UU No. 20 Tahun 2003 tentang Sisdiknas, menginginkan manusia yang beriman, bertaqwa dan berakhlak mulia, dan seterusnya.

Hakikat tujuan pendidikan nasional (aims) yang dirumuskan dalam kedua UU di atas menekankan betapa pendidikan nasional diharapkan dapat menciptakan karakter manusia Indonesia yang religius dan bermoral, menguasai ilmu pengetahuan dan keterampilan, sehat jasmani dan rohani, berkepribadian dan bertanggung jawab. Tujuan pembentukan karakter manusia tersebut bersifat universal, normatif, dan abstrak yang harus diterjemahkan ke dalam rumusan operasional (goals). Goals merupakan tujuan yang terletak antara aims dan objectives (tujuan yang dicapai sebagai hasil belajar). Dengan kata lain, goals adalah hasil proses belajar menurut suatu sistem sekolah. Tingkat tujuan yang lebih rendah dari goals adalah objectives (objektif), yaitu tujuan suatu unis atau pokok bahasan yang lebih spesifik yang merupakan hasil proses belajar di kelas. Karena itu, untuk menterjemahkan ke dua tujuan (aims) UU di atas, perlu strategi dalam mengelola sistem pendidikan yang sesuai dengan arah perkembangan 
karakter bangsa Indonesia saat ini. Smith, Stanley, dan Shores (Ansyar, 1989:95), mengembangkan kriteria penetapan tujuan secara substantif dan prosedural. Secara substantif mencakup sumber-sumber empiris tentang pelajar, masyarakat, ilmu pengetahuan (mata pelajaran), dan filafat, sedangkan secara prosedural mencakup keterwakilan (representatif), kejelasan, terpertahankan, konsistensi, dan kelayakan.

Arah perkembangan karakter bangsa Indonesia saat ini dihadapkan pada milenium ke tiga era globalisasi, baik iptek, politik, ekonomi, sosial budaya, komunikasi, transportasi maupun kehidupan keagamaan. Dalam era modern semacam ini, hanya bangsa yang memiliki pendidikan dan sumber daya manusia yang berkualitas akan mampu mengelola proses pendidikan, mengembangan iptek, dan menciptakan sumber daya manusia yang dapat bersaing dengan bangsa lain. Agar dapat bertahan sebagai negara yang bermartabat, bangsa Indonesia memerlukan sistem pendidikan yang dapat menciptakan sumber daya manusia yang berkualitas yang mampu menangkal berbagai persoalan global.

Berangkat dari pemahaman tentang karakteristik masyarakat moderen di atas, maka dapat diidentifikasi bahwa pembentukan karakter yang perlu dikuasai dan dimiliki oleh bangsa Indonesia saat ini adalah : (1) memiliki kemampuan, nilai dan sikap yang mampu berpartisipasi secara aktif dan cerdas dalam pembangunan nasional, (2) memiliki kemampuan disiplin dan etos kerja yang dapat secara aktif dan produktif berpartisipasi dalam berbagai kegiatan, (3) memiliki kemampuan sikap ilmiah, menguasai dan mampu mengembangkan iptek, (4) memiliki kepribadian, berkarakter, bermoral, dan berakhlak mulia.

\section{Materi yang Relevan bagi Kedudukan Kurikulum}

Materi merupakan komponen kurikulum yang sangat strategis dalam proses pendidikan. Oleh sebab itu, perlu pemahaman tentang hakikat struktur materi yang akan diajarkan. Sebelum menganalisis materi yang relevan dengan arah perkembangan karakter bangsa Indonesia, berikut adalah gambaran materi yang tertuang dalam kurikulum berdasarkan UU No. 2 Tahun 1989 dan UU No. 20 tahun 2003 untuk pendidikan tingkat dasar maupun tingkat menengah:

\begin{tabular}{l|l}
\hline \multicolumn{1}{c|}{ UU No. 2 Tahun 1989 } & \multicolumn{1}{|c}{ UU No. 20 Tahun 2003 } \\
\hline Pendidikan Agama & Pendidikan Agama \\
Pendidikan Pancasila & Pendidikan Kewarganegaraan \\
Pendidikan Kewarganegaraan & Pendidikan Agama \\
Bahasa Indonesia & Bahasa \\
Membaca dan Menulis & Matematika \\
Matematika termasuk Berhitung & Ilmu Pengetahuan Alam \\
Pengantar Sains dan Teknologi & Ilmu Pengetahuan Sosial \\
Ilmu Bumi & Seni budaya dan Olah raga \\
Sejarah Nasional dan & Keterampilan, Kesenian dan Muatan \\
Sejarah Umum Lokal & lokal \\
Kerajinan tangan dan Kesenian & \\
Pendidikan Jasmanani dan Kesehatan & \\
Menggambar & \\
Bahasa Inggris & \\
\hline
\end{tabular}

Kandungan materi yang tertuang dalam ke dua rancangan kurikulum di atas, merupakan kelompok ilmu pengetahuan yang telah terakumulatif (accumulated knowledge) demikian luas secara permanen dan mencakup tiga komponen utama, yaitu ilmu pengetahuan, proses, dan 
nilai-nilai. Oleh sebab itu, perlu dipilih yang lebih esensial yang kriterianya lebih mengarah pada kebutuhan peserta didik dan tujuan yang hendak dicapai. Artinya, pengetahuan yang dituangkan ke dalam bentuk materi harus mengandung kekhususan (realms of meaning), baik dari konsep, metode, maupun struktur pengetahuannya.

Pemerintah sebagai pihak yang merancang kurikulum (sentralistik) seharusnya dalam menetapkan kurikulum didasari pertimbangan bahwa, ilmu pengetahuan yang diberikan kepada peserta didik dalam bentuk materi harus menjadi miliknya dan bermanfaat. Dengan kata lain, penetapan materi kurikulum tidak hanya dipilih sebagai materi saja, tetapi dipilih sebagai ilmu pengetahuan yang dapat membentuk perilaku anak sesuai dengan kebutuhan dan perkembangan yang akan terjadi.

Hymen (Ansyar, 1989:115), mendefinisikan materi sebagai; ilmu pengetahuan (seperti; fakta, keterangan, prinsip-prinsip, definisi), keterampilan dan proses (seperti; membaca, menulis, berhitung, menari, berpikir kritis, berkomunikasi lisan dan tulisan), dan nilai-nilai (seperti; konsep tentang hal-hal baik, buruk, benar dan salah, indah dan jelek). Sedangkan Saylor dan Alexander (Ansyar, 1989:115), mendefinisikan materi sebagai fakta, observasi, data, persepsi, klasifikasi, disain, dan pemecahan masalah yang telah dihasilkan pengalaman dan hasil pikiran manusia yang tersusun dalam bentuk ide-ide, konsep, prisip-prinsip, kesimpulan, perencanaan dan solusi. Dari kedua definisi tersebut secara umum dapat dipahami, bahwa materi kurikulum mencakup tiga komponen utama, yaitu ilmu pengetahuan, proses, dan nilainilai.

Penetapan materi kurikulum harus didasarkan pada beberapa hal. Dasar yang paling utama adalah tujuan umum (tujuan instusional, tujuan kurikuler) ataupun tujuan khusus, seperti tujuan instruksional. Menurut Nasution (1982:190), terdapat sejumlah kriteria dalam menentukan materi pelajaran dalam sebuah kurikulum, yaitu: (a) Bahan pelajaran dipilih berdasarkan tujuan yang hendak dicapai. (b) Bahan pelajaran dipilih karena dianggap berharga sebagai warisan generasi yang lampau. (c) Bahan pelajaran dipilih karena berguna untuk menguasai satu disiplin. (d) Bahan pelajaran dipilih karena dianggap berharga bagi manusia dalam hidupnya. (e) Bahan pelajaran dipilh karena sesuai dengan kebutuhan dan minat anak.

Bagi praktisi pendidikan utamanya guru, hingga saat ini dalam mengimplementasikan dan mengembangkan materi merupakan suatu persoalan yang sulit. Hal ini disebabkan oleh pembuat kebijakan adalah pemerintah, sedangkan eksplorasi ilmu pengetahuan dan perkembangan budaya masyarakat di era globalisasi tidak dapat dibendung, sehingga akan berpengaruh terhadap pencapaian tujuan pendidikan. Agar pengetahuan (materi) yang tertuang dalam kurikulum yang berlaku tetap relevan dengan tuntutan zaman, pola desentralisasi sangat tepat bila diterapkan kepada masing-masing lembaga dalam penyusunan kurikulum. Dengan demikian, penulis berpandangan bahwa kurikulum yang diberlakukan secara sentralisasi berdasarkan UU masih relevan walaupun kandungannya luas.

Implementasi kurikulum dalam proses pembelajaran bukan memberikan sesuatu pada anak, melainkan harus dapat menumbuhkan dan mengembangkan semua potensi yang ada pada anak. Oleh sebab itu, anak dijadikan objek kegiatan pengajaran dan sebagai sumber penyusunan kurikulum. Dengan demikian, dalam penetapan materi harus memberikan kontribusi kepada peserta didik untuk dapat mengembangkan potensinya. Materi yang relevan harus dapat mengarahkan pada pembentukan perilaku yang diinginkan oleh peserta didik berupa pengetahuan, keterampilan, dan sikap secara seimbang. Selain itu, faktor lain yang harus dipertimbangkan adalah timbulnya berbagai tuntutan baru yang harus dimiliki peserta didik pada saat melaksanakan proses pendidikan, seperti mampu berpikir kritis, kreatif dan aktif, memahami lingkungan sosial, globalisasi, dan sebagainya. 


\section{Pendekatan Proses Pembelajaran}

Proses pembelajaran akan bermakna sebagai proses penguasaan dan penggunaan ilmu pengetahuan bila melibatkan semua potensi yang dimiliki oleh peserta didik. Potensi-potensi tersebut meliputi intelektual, emosional, dan fisik (soft skill dan hard skill). Oleh sebab itu, pendekatan pembelajaran biasanya disusun berdasarkan prinsip atau teori-teori belajar tertentu sebagai pijakan dalam pelaksanaannya. UNESCO dan UNICEF pada tahun 1999 bekerjasama dengan Depdiknas mengembangkan program CCLC (Creating Learning Communities for Children) atau yang lebih dikenal dengan Manajemen Berbasis Sekolah (MBS). Salah satu program MBS adalah PAKEM (Pembelajaran partisipatif, aktif, kreatif, dan menyenangkan), yang sesuai dengan prinsip pembelajaran harus berpusat pada anak (student centered learning). PAKEM menterjemahkan empat pendekatan model atau pilar belajar, yaitu larning to know, learning to do, learning to be, dan learning to live together.

\section{Learning to know (belajar mengetahui)}

Learning to know menekankan aspek kognitif siswa. Dalam perolehan pengetahuan, siswa berusaha berpartisipasi secara aktif dan kreatif mencari, menemukan, menganalisis dan menyimpulkan pengetahuan melalui pengalaman belajarnya yang dibimbing oleh guru. Belajar dipandang sebagai proses yang diarahkan guru kepada proses berbuat melalui pengalaman yang menyenangkan. Oleh sebab itu, siswa dituntut untuk dapat berpartisipasi secara aktif dan kreatif dalam memecahkan berbagai persoalan belajar. Dalam learning to know terkandung unsur learning how to learn, yaitu siswa dalam aktivitas belajarnya dituntut untuk aktif dan kreatif dalam melihat, mengamati, dan memahami tentang yang terdapat di lingkungan sekitar tempat ia belajar berdasarkan kemampuannya. Peran guru dalam learning to know adalah sebagai sumber belajar, fasilitator, pengelola, demonstrator, pembimbing, mediator, dan evaluator. Selain itu, juga guru harus dapat memberikan pelayanan yang menyenangkan bagi siswanya.

\section{Learning to do (belajar melakukan)}

Learning to do, yaitu proses belajar yang menekankan kepada siswa untuk dapat melakukan sesuatu dari hasil pengalaman belajarnya. Tujuan pembelajaran yang ingin dicapai adalah selain untuk penguasaan pengetahuan dan sikap, tetapi yang utama adalah tercapainya keterampilan. Sehingga siswa selain memiliki bekal pengetahuan dan sikap, tetapi juga memiliki keterampilan untuk memasuki dunia kerja. Dalam pembelajaran, potensi siswa yang terlibat mencakup intelektual, emosional, dan fisik (hard skill dan soft skill). Partisipasi hard skill dan soft skill sangat dipentingkan dalm melakukan, mencoba, mengalami sendiri, menganalisis, dan menyimpulkan pengetahuan. Dengan kegiatan seperti ini, diharapkan siswa dapat secara optimal menguasai pengetahuan dan sekaligus menerapkan dalam konteks kehidupan aktual.

Model pembelajaran CTL (contekstual teaching and learning) merupakan salah satu konsep belajar yang dapat membantu guru mengaitkan antara yang diajarkan dengan situasi dunia nyata, sehingga mendorong siswa membuat hubungan antara pengetahuan yang dimilikinya dengan penerapannya dalam kehidupan mereka di masyarakat. Menurut Rusman (2010:190), CTL adalah pembelajaran yang memungkinkan terjadinya proses belajar dimana siswa menggunakan pemahaman dan kemampuan akademiknya dalam berbagai konteks dalam dan luar sekolah untuk memecahkan masalah yang bersifat simulatif ataupun nyata, baik sendiri-sendiri maupun bersama-sama. Untuk memperkuat dimilikinya pengalaman belajar yang aplikatif bagi siswa, tentu saja diperlukan pembelajaran yang lebih banyak memberikan kesempatan bagi siswa untuk melakukan, mencoba, menganalisis, dan mengalami sendiri (learning to do). Melalui pembelajaran CTL, mengajar bukan transformasi pengetahuan dari guru kepada siswa, tetapi lebih ditekankan kepada upaya memfasilitasi siswa untuk mencari kemampuan untuk bisa hidup (life skill) dari yang dipelajarinya. 


\section{Learning to be (belajar menjadi diri sendiri)}

Learning to be diartikan bahwa proses belajar dilakukan untuk pembentukan individu menjadi diri sendiri berupa aspek kepribdian dan kesesuaian dengan diri anak. Proses belajar diharapkan dapat membantu siswa dalam menumbuhkembangkan potensi-potensi keindividuannya. Potensi-potensi yang dimiliki siswa merupakan benih kemungkinan untuk menjadi individu yang berkembang. Oleh sebab itu, tugas pendidikan hanya mungkin dilakukan dengan benar dan tepat, jika pendidik memiliki gambaran yang jelas tentang perkembangan potensi individu tersebut. Tiga potensi individu yang harus dimaksimalkan oleh guru saat melaksanakan pembelajaran dalam pembentukan diri adalah kognitif, afektif, dan psikomotor (cipta, rasa, dan karsa). Guru tidak boleh mengabaikan satupun potensi yang dimiliki peserta didik untuk tidak diproses. Artinya, pembentukan potensi tersebut harus terbentuk secara seimbang pada diri setiap peserta didik setelah mengikuti proses pembelajaran.

Proses pembentukan pribadi pendidikan diartikan sebagai suatu kegiatan yang sistematis dan sistemik terarah pada terbentuknya kepribadian peserta didik. Sistematis oleh karena pendidikan berlangsung melalui tahap-tahap perkembangan (procedural), dan sistemik berlangsung dalam semua situasi kondisi di semua lingkungan (keluarga, sekolah, dan masyarakat). Tirtarahardja (2000:34), dalam proses pembelajaran pembentukan pribadi (individu) meliputi dua sasaran, yaitu pembentukan bagi mereka yang belum dewasa oleh mereka yang sudah dewasa, dan bagi mereka yang sudah dewasa atas usahanya sendiri. Bagi guru memahami konsep learning to be sangat penting, karena bertanggung jawab dalam membentuk siswa melalui kegiatan pendidikan agar menjadi mandiri dan percaya diri ketika hidup di masyarakat.

\section{Learning to live together (belajar hidup bersama)}

Learning to live together menekankan pada aspek sosial anak dalam belajarnya, yaitu bagaimana peserta didik bersosialisasi dan bertoleransi dalam keberagaman yang ada di sekeliling peserta didik. Learning to live together merupakan reflektif dari salah satu dimensi hakikat kemanusiaan, yaitu dimensi kesosialan. Dimensi kesosialan pada individu tampak dari adanya dorongan untuk berinteraksi dengan yang lainnya. Manusia akan menjadi manusia jika berada di antara manusi. Oleh sebab itu, konsep learning to live together menekankan kepada peserta didik pentingnya belajar bekerja sama dan tidak semata-mata hanya menekankan pada isi atau hasil. Hal ini disebabkan oleh adanya dimensi kesosialan pada diri siswa, sehingga siswa akan mengoptimalkan potensi yang dimilikinya melalui interaksi sosial.

Pendekatan PAKEM dapat dijadikan solusi untuk diterapkan pada penyelenggaraan pengajaran nasional, baik ditingkat pendidikan dasar maupun mengengah. Dalam PAKEM menterjemahkan empat pendekatan pilar belajar; learning to know, learning to do, learning to be, dan learning to live together.

Ada beberapa alasan mengapa strategi PAKEM dijadikan solusi dalam proses pembelajaran saat ini: (a) Model belajar yang lama cenderung membuat siswa bosan, jenuh, dan interaksi tidak optimal, bahkan cenderung satu arah. (b) Keterlibatan siswa dalam mengolah pengetahuan sangat minimal (pasif), sebab yang menjadi motor utama dalam proses belajar adalah guru. (c) Tujuan pembelajaran (kompetensi) sukar dicapai.

Inti PAKEM (pembelajaran partisipatif, aktif, kreatif, efektif, dan menyenangkan), oleh Rusman (2000:323), diterjemahkan sebagai berikut:

Pembelajaran partisipatif, yaitu proses pembelajaran yang melibatkan siswa secara optimal. Baik fisik maupun psikis (hard skill dan soft skill). Pembelajaran aktif, yaitu pembelajaran yang melibatkan aktivitas siswa dalam mengakses informasi dan pengetahuan untuk dibahas dan dikaji dalam proses pembelajaran. Pembelajaran kreatif, merupakan proses pembelajaran yang mengharuskan guru untuk dapat memotivasi dan memunculkan kreativitas siswa dalam pembelajaran. Pembelajaran efektif, jika mampu memberikan pengalaman baru 
kepada siswa. Pembelajaran menyenangkan, merupakan proses pembelajaran yang di dalamnya terdapat suatu kohesi yang kuat antara guru dan siswa, tanpa ada perasaan terpaksa dan tertekan. Terdapat beberapa model pembelajaran yang biasa digunakan oleh guru yang pada dasarnya mendukung PAKEM, yaitu pembelajaran kuantum (quantum teaching), pembelajaran berbasisi kompetensi, dan CTL (Contextual Teaching and Learning).

Tujuan diterapkannya PAKEM didasari oleh adanya perubahan paradigma bahwa pendidikan di Indonesia saat ini sudah harus beranjak dari; (a) schooling menjadi learning, (b) instructive menjadi facilitative, (c) government role menjadi community role, dan (d) centralistic menjadi decentralistic. Perubahan paradigma juga harus terjadi bahwa pada kondisi sekarang ini, peran guru harus menjadi fasilitator yang dapat membantu siswa dalam belajar, bukan hanya sekedar menyampaikan materi saja tanpa mengetahui apakah materi yang disampaikan itu sudah bisa dipahami oleh siswa atau belum. Begitu juga terhadap paradigma dalam pengambilan keputusan. Dulu keputusan selalu ada di pemerintah pusat, tanpa memperhatikan aspek-aspek yang terjadi di masing-masing daerah atau satuan-satuan pendidikan, namun sekarang menjadi keputusan yang bisa diambil secara desentralisasi dengan mengacu pada pemerintah pusat.

Dalam setiap penerapan modelpembelajaran tentu ada keunggulan maupun kelemahannya. Keunggulan PAKEM selain proses pembelajaran menjadi menyenagkan dan bermakna siswa juga keterampilan social dan komunikasi menjadi terasah. Sedangkan kelemahannya; dibutuhkan waktu lama, guru harus inovatif, kreatif dan terampil, membutuhkan biaya besar, dan persiapan yang matang. Pembelajaran PAKEM merupakan pembelajaran yang menekankan partisipasi aktif, kreatif, dan inovatif, sehingga proses pembelajaran menjadi menyenangkan dan menjadi pedoman untuk mencapai tujuan yang telah ditetapkan. Dengan pelaksanaan pembelajaran PAKEM, diharapkan berkembangnya berbagai macam inovasi kegiatan pembelajaran untuk mencapai tujuan pembelajaran yang partisipatif, aktif, kreatif, dan menyenangkan.

\section{Evaluasi Proses Pembelajaran}

Arikunto (2012:3), mendefinisikan evaluasi merupakan sebuah proses pengumpulan data untuk untuk menentukan sejauh mana, dalam hal apa dan bagian mana tujuan pendidikan pendidikan sudah tercapai. Evaluasi juga dapat diartikan sebagai kegiatan yang direncanakan untuk mengetahui keberhasilan suatu objek dengan melibatkan instrumen dalam pengolahannya dan hasilnya dibandingkan dengan kriteria tertentu sehingga diperoleh kesimpulan. Dengan demikian, evaluasi dapat diartikan sebagai kegiatan yang dilakukan dalam pengumpulan informasi dengan mengamati, menelaah, dan mengukur guna menarik kesimpulan atau mengambil keputusan.

Lebih lanjut Sukardi (2012:9), menguraikan sejumlah tujuan evaluasi dalam proses pembelajaran, antara lain (a) menilai ketercapaian tujuan, (b) mengukur aspek belajar, (c) merupakan saran untuk mengetahui apa yang telah siswa ketahui, (d) sebagai motivasi siswa, (e) menyediakan informasi terkait bimbingan dan konseling, dan (f) menjadikan hasil evaluasi sebagai dasar perubahan atau pengembangan kurikulum. Dapat disimpulkan bahwa, tujuan evaluasi adalah untuk mengukur ketercapaian atau keberhasilan suatu program telah dilaksanakan.

Banyak model evaluasi yang dikembangkan para ahli guna mengevaluasi program pembelajaran. Salah satu model evaluasi yang dapat digunakan dalam proses pembelajaran PAKEM adalah model evaluasi yang dikembangkan oleh Stufflebeam, yaitu evaluasi CIPP (Contex, Input, Prosess and Product). Evaluasi CIPP merupakan kerangka yang komperhensif untuk mengarahkan pelaksanaan evaluasi formatif dan evaluasi sumatif terhadap objek program, projek, personalia, produk, institusi, dan sistem. 
Dalam evaluasi context, tujuannya untuk mengidentifikasi masalah yang muncul dan peluang yang dibutuhkan dalam konteks pendidikan sebagai dasar pengembangan dan perbaikan program pembelajaran, sehingga dapat membantu para pengambil keputusan (terutama guru) dalam menetapkan dan merencanakan tujuan yang ingin dicapai. Evaluasi input, ditujukan untuk membantu para pengambil keputusan dalam menentukan alternatif sumber-sumber yang akan digunakan proses pendidikan, sekaligus menentukan, strategi, dan prosedur pencapaian program yang akan dilaksanakan. Evaluasi process, diarahkan untuk mengetahui terlaksana atau tidaknya program yang telah direncanakan dengan melibatkan berbagai komponan yang ada. Selain itu evaluasi ini juga berfungsi untuk melakukan deteksi dan prediksi yang terkait dengan prosedur pelaksanaan program. Evaluasi product, bertujuan untuk menilai, mengukur, dan menginterpretasikan pencapaian tujuan program. Evaluasi produk juga bertujuan mendeskripsi, menginterpretasikan, dan merekomendasikan kebermaknaan program yang sedang dan telah dilaksanakan. Hal lain, evaluasi produk juga merupakan penilaian terhadap hasil (luaran) dari procces.

Dari uraian di atas, dapat disimpulkan bahwa dalam evaluasi CIPP tidak hanya mengevaluasi hasil (product) saja, melainkan seluruh aspek secara komperehensif yang terlibat dalam proses pembelajaran. Aspek-aspek yang dimaksud adalah; context, input, process dan product.

Menurut Nasution (1989), tujuan evaluasi yang komperehensif dapat ditinjau dari tiga dimensi yang masing-masing dimensi memiliki dua komponen. Ketiga dimensi yang dimaksud dapat dilihat pada tabel sebagai berikut :

\begin{tabular}{|c|c|}
\hline \multicolumn{2}{|l|}{ Dimensi I } \\
\hline Formatif & $\begin{array}{l}\text { Evaluasi dilakukan sepanjang pelaksanaan pembelajaran. Data } \\
\text { dikumpulkan dan dianalisis untuk menemukan masalah serta mengadakan } \\
\text { perbaikan sedini mungkin. }\end{array}$ \\
\hline Sumatif & $\begin{array}{l}\text { Evaluasi dilkukan pada akhir pembelajaran untuk mengetahui efektivitas } \\
\text { pembelajaran dengan menggunakan semua data yang dikumpulkan } \\
\text { selama pelaksanaan dan akhir proses pembelajaran. }\end{array}$ \\
\hline \multicolumn{2}{|l|}{ Dimensi II } \\
\hline Proses & $\begin{array}{l}\text { Yang dievaluasi adalah metode dan proses pembelajaran. Tujuannya } \\
\text { untuk mengetahui metode dan proses yang digunakan, tepat tidaknya } \\
\text { penggunaan, dan kesulitan yang dihadapi. }\end{array}$ \\
\hline Produk & $\begin{array}{l}\text { Yang dievaluasi adalah hasil-hasil nyata, yang dapat dilihat, seperti; } \\
\text { silabus, RPP, dan alat-alat pelajaran yang dihasilkan oleh guru, hasil } \\
\text { belajar siswa berupa hasil tes, dan lain-lain. }\end{array}$ \\
\hline \multicolumn{2}{|l|}{ Dimensi III } \\
\hline Operasi & $\begin{array}{l}\text { Proses pembelajaran dievaluasi secara keseluruhan, meliputi; kurikulum, } \\
\text { perencanaan, disain, implementasi, administrasi, pengawasan, } \\
\text { pemantauan dan penilaiannya, anggaran, guru, penerimaan peserta didik, } \\
\text { dan lain-lain. }\end{array}$ \\
\hline $\begin{array}{l}\text { Hasil belajar } \\
\text { siswa }\end{array}$ & $\begin{array}{l}\text { Yang dievaluasi adalah hasil belajar siswa yang bertalian dengan tujuan } \\
\text { pembelajaran yang harus dicapai, nilai berdasarkan standar yang telah } \\
\text { ditentukan, misi lembaga pendidikan, dan tuntutan dari pihak konsumen } \\
\text { luar. }\end{array}$ \\
\hline
\end{tabular}

Dengan demikian, ada keunggulan ketika proses pembelajaran PAKEM menerapkan evaluasi CIPP, yaitu tujuan-tujuan yang akan dievaluasi bersifat komperehensif. Tidak hanya komponen pengetahuan, keterampilan, dan sikap saja, tetapi juga meliputi seluruh aspek yang 
terlibat dalam proses pendidikan. Tentunya ini akan memberikan gambaran yang luas tentang hasil yang diinginkan. Evaluator, termasuk guru dalam melaksanakan tugasnya tidak hanya fokus pada pengetahuan akademis saja (soft skill), tetapi juga menyangkut pertumbuhan kepribadian siswa (hard skill), seperti minat, sikap, apresiasi, dan penyesuaiannya secara emosional dan sosial. Selain komperehensif, evaluasi CIPP juga berkesinambungan dan saling berkaitan (inter-related) dengan kurikulum.

Kelemahan model evaluasi CIPP adalah tingkat keterlaksanaannya yang rendah, sebab harus mengkombinasikan semua aspek yang akan dinilai, yaitu context, input, prosess and product. Hal ini akan melibatkan kolaborasi banyak pihak yang berkompeten sehingga membutuhkan waktu dan biaya lebih.

\section{Peran Guru}

Dalam kegiatan pendidikan, guru harus tampil profesional untuk mencapai tujuan pendidikan yang berupa perkembangan siswa secara optimal. Untuk maksud tersebut, peran profesional itu salah satunya adalah melaksanan proses pembelajaran. Proses pembelajaran menempati porsi terbesar dari peran guru, sebab tugas utama guru adalah mengajar, membimbing, melatih, dan mengembangkan kurikulum, sehingga tercipta suasana yang kondusif, yaitu suasana belajar yang memberikan rasa aman, menyenangkan, menarik, siswa bertindak aktif, berpikir kreatif, dan inovatif dalam mengelaborasi dan mengeksplorasi kemampuannya. Guru profesional merupakan faktor penentu proses pendidikan yang berkualitas. Untuk menjadi profesional, guru harus mampu menentukan jati diri dan mengaktualisasikan diri sesuai dengan kemampuan dan kaidah-kaidah profesional yang dipersyaratkan.

Luapan perkembangan ilmu pengetahuan dan teknologi serta kemajuan dan perkembangan masyarakat, membawa konsekuensi serta persyaratan yang semakin berat dan kompleks bagi guru. Akibatnya, peran guru bukan lagi hanya sekedar mengajar (transfer of knowledge), tetapi juga harus menjadi sumber belajar. Hal tersebut mengandung arti bahwa, setiap guru harus mampu menciptakan kondisi, strategi, dan menerapkan pendekatanpendekatan belajar yang tepat, sehingga dapat menantang aktivitas, kreativitas, dan memotivasi siswa dalam mengolah pengetahuan.

Persoalan-persoalan guru yang muncul dalam melaksanakan proses pembelajaran saat ini yang terkait dengan perannya adalah rendahnya kompetensi (terutama kompetensi pedagogis) yang dimiliki, ketidaksesuaian disiplin ilmu dengan mata pelajaran yang diampu, kualifikasi keilmuan yang rendah, dan malas mengembangkan keterampilan. Tentunya persoalan tersebut harus direspon oleh semua pihak, terutama pemerintah sebagai penanggung jawab pelaksana pendidikan.

Model PAKEM yang dijadikan solusi pada penyelenggaraan sistem pengajaran nasional, guru harus mampu menciptakan suasana pembelajaran yang partisipatif, aktif, kreatif, dan menyenangkan agar siswa dapat menguasai kompetensi yang diharapkan. Menurut Rusman (2010:324-327), beberapa prinsip yang menjadi fokus guru dalam melaksanakan PAKEM adalah:

1) Keterlibatan intelektual, emosional, dan fisik (hard skill dan soft skill) siswa dalam mengolah pengetahuan harus diutamakan.

2) Guru harus dapat menciptakan komunikasi yang baik antara siswa dengan siswa maupun siswa dengan guru.

3) Menciptakan interaksi multi arah antara siswa dengan siswa, siswa dengan guru atau siswa dengan lingkungan bisa dioptimalkan

4) Untuk mengukur keberhasilan, proses refleksi harus dilakukan oleh guru.

Perkembangan masyarakat dan iptek memberikan konsekuensi persyaratan yang semakin berat dan kompleks bagi guru. Pendidikan yang berkualitas sebagaimana yang diharapkan oleh 
masyarakat modern sifatnya selalu menantang, sehingga mengharuskan guru memiliki kemampuan profesional, personal, sosial, dan pedagogis dalam melaksanakan kegiatan pendidikannya.

\section{SIMPULAN}

Kedudukan kurikulum di sekolah sangat strategis karena sekolah merupakan proses pembudayaan berbagai penguasaan ilmu pengetahuan melalui proses pembelajaran yang bermakna. Proses pembelajaran yang demikian hanya akan terjadi secara efektif dan efisien apabila sistem kurikulum dirancang secara terencana, terstruktur dan sistematik, mulai dari penentuan tujuan, pemilihan materi, proses pembelajaran, dan evaluasi yang komperehensif. Setiap pengetahuan yang dituangkan ke dalam materi harus mengandung kekhususan (realms of meaning) baik dalam konsep, metode, maupun struktur pengetahuannya.

Proses pembelajaran akan bermakna bila di dalam prosesnya melibatkan intelektual, emosional, maupun fisik (soft skill dan hard skill) peserta didik. Pendekatan PAKEM (pembelajaran partisipatif, aktif, kreatif, efektif, dan menyenangkan) dapat dijadikan solusi untuk diterapkan pada strategi penyelenggaraan sistem pengajaran nasional. Dalam PAKEM menterjemahkan empat pedekatan pilar belajar; learning to know, learning to do, learning to be, dan learning to live together.

Salah satu model evaluasi yang dapat digunakan dalam PAKEM adalah model evaluasi yang dikembangkan oleh Stufflebeam, yaitu evaluasi CIPP (context, input, proses, dan product). Evaluasi CIPP merupakan kerangka yang komperehensif untuk mengarahkan pelaksanaan evaluasi formatif dan evaluasi sumatif terhadap objek program, projek, personalia, produk, institusi, dan sistem.

Dalam PAKEM, guru harus mampu menciptakan suasana pembelajaran partisipatif, aktif, kreatif, dan menyenangkan sehingga siswa dapat menguasai kompetensi yang diharapkan. Untuk itu, guru harus memiliki pengetahuan yang luas mengenai model-model belajar. Guru juga dituntut untuk melakukan kegiatan pembelajaran yang dapat melibatkan siswa melalui partisipatif, aktif, kreatif, dan menyenangkan yang pada akhirnya siswa dapat menciptakan karya, gagasan, pendapat, ide atas hasil penemuannya dan usahanya sendiri, bukan dari gurunya. Sehingga secara keseluruhan dalam proses pembelajaran peran guru meliputi banyak hal, yaitu sebagai pengajar, pemimpin kelas, pembimbing, pengatur lingkungan belajar, perencana pembelajaran, innovator, motivator, supervisor, dan sebagai evaluator.

\section{DAFTAR RUJUKAN}

Ansyar, M. (1989). Dasar-Dasar Pengembangan Kurikulum. Dirjen Dikti PPLP Tenaga Kependidikan. Jakarta: Depdikbud.

Arikunto, S.(2012). Dasar-Dasar Evaluasi Pendidikan. Jakarta: Bumi Aksara.

Denim, S. (2010). Profesional dan Etika Profesi Guru. Bandung: Alfabeta.

Dimyati. (2006). Belajar dan Pembelajaran. Jakarta: Asdi Mahasatya.

Hasan, H. (2009). Evaluasi Kurikulum. Cetakan kedua. Bandung: Remaja Rosdakarya.

Nasution, S. (2009). Berbagai Pendekatan dalam Proses Belajar dan Mengajar. Jakarta: Bumi Aksara.

Nasution, S. (2009). Kurikulum dan Pengajaran. Jakarta: Bumi Aksara.

Rusman.(2010).Seri Manajemen Sekolah Bermutu Model-Model Pembelajaran Mengembangkan Profesionalisme Guru. Jakarta: Rajawali Pers. Rajagrafindo Persada. 
Syaodih Sukmadinata, N. (2000). Pengembangan Kurikulum Teori dan Praktek. Bandung: Remaja Rosdakarya.

Tirtarahardja, U \& La Sula. (2000). Pengantar Pendidikan. Jakarta: Departemen Pendidikan dan Kebudayaan dan Rineka Cipta.

Undang-Undang Sisdiknas Nomor 20 Tahun 2003. 